\title{
Szemle
}

\author{
KISS JÁNOS MÁRK*
}

\section{A betegjogok alapjogi háttere a német és a magyar betegjogi szabályozás fejlődésének tükrében}

\author{
betegjogok - alapvetö emberi jogok - orvos-beteg jogviszony - \\ kezelési szerződés
}

Az egészségügyi szolgáltatás, akár egy összetett mütéti beavatkozásról, akár egy egyszerủ vizsgálatról van szó, szükségképpen érinti az emberi személyiség legalapvetőbb alkotóelemeinek valamelyikét: az emberi élet, testi épség és egészség megőrzése, helyreállítása, illetve megmentése nem képzelhető el az ezeket érintő külső behatás nélkül. Bár a beteg meggyógyítása, mint társadalmilag és jogilag elismert cél, legitimálja a személyiségi jogokat érintő beavatkozást, a kezelést igénybe vevő személy egészségi állapota, illetve az ezzel kapcsolatos szakismeretek hiánya miatt kiszolgáltatott helyzetbe kerülhet az ellátás során.

A fent leírtak az orvostudomány, illetve az egészségügyre vonatkozó szabályozás fejlődésének bármely szakaszában elmondhatók voltak, a jogalkotó azonban a 20. század közepéig nem ismerte fel, hogy szükség van a beteg pozíciójának erősítését biztosítani képes jogi garanciákra. Annak elismerése tehát, hogy a betegnek az egészségügyi beavatkozások fölött a lehető legteljesebb körű kontrollal kell bírnia, az első, nagyobb jelentőségú emberi jogi egyezmények ${ }^{1}$ létrejöttének időszakára tehető.

A betegjogok körében olyan jogosultságokról beszélünk, amelyek az egészségügyi szolgáltatást igénybe vevő személyt emberi mivoltánál fogva megilletik, függetlenül attól, hogy milyen jogviszony alapján részesül ellátásban. Az egészségügyi ellátások fent említett sajátosságaira tekintettel jogállami keretek között elvárható,

\footnotetext{
* Dr. Kiss János Márk PhD-hallgató, Debreceni Egyetem Marton Géza Állam- és Jogtudományi Doktori Iskola; ügyvédjelölt, Dr. Marsi Edit Ügyvédi Iroda; kissjanosm@gmail.com.

1 ENSZ alapokmány (1945); Emberi Jogok Egyetemes Nyilatkozata (1948).
} 
hogy a jogalkotó meghatározza azokat a törvényi garanciákat, amelyek valamennyi beteg számára biztosítják az emberi jogok érvényesülését az egészségügyi ellátás során. A betegjogok tehát az úgynevezett csoportjogok körébe sorolhatók, amelyek ugyan elválnak az alkotmányos szabályozástól, mégis az emberi jogoknak az egészségügy területén való konkretizálásaként foghatók fel. ${ }^{2}$

Jelen tanulmány célja, hogy a magyar és a német betegjogi szabályozás kialakulásának és fejlődésének folyamatát áttekintve bemutassa a betegjogok emberi jogi hátterét, illetve arra vonatkozó következtetéseket vonjon le, hogy vajon hogyan érvényesülnek a betegjogok az ellátás nyújtására irányuló jogviszonyban. A szabályozás mögött húzódó megfontolás, jelesül a beteg autonómiájának, illetve alapvető jogainak védelme - a fentebb leírtakat figyelembe véve - a két jogrendszer esetében megegyezik. Németországban azonban az egészségügyi szolgáltatás nyújtására irányuló jogviszonyt önálló szerződéstípusként szabályozták, a jogalkotó ennek keretei között rögzítette a beteg autonómiájának biztosítását célzó garanciákat. Hazánkban ezzel szemben az egészségügyi ágazati szabályozás foglalkozik a betegjogokkal. Amellett pedig, hogy a két jogrendszer teljesen eltérő szabályozási módszert alkalmaz, a beteget az egészségügyi ellátással összefüggésben megillető, nevesített jogok köre is különbözik. A fenti eltérések megfelelő alapot nyújtanak ahhoz, hogy az összehasonlítás eredményeképp megalapozott általános következtetéseket lehessen levonni a betegjogok alapjogi háttere és az „orvos-beteg” jogviszonyhoz való kötődése kapcsán.

\section{A betegjogok mibenléte}

A beteget az egészségügyi szolgáltatások igénybevételével összefüggésben megillető jogokat a köznyelv és a szakirodalom is betegjogokként ismeri. Bár a betegjog önálló jogi fogalomként nem létezik, ${ }^{3}$ a szabályozás módszerére, a jogok univerzalitására, illetve az általuk védett jogi tárgyra tekintettel mégis önálló jogi kategóriaként kezelhetök.

A betegjogok az egészségügyi szolgáltatáshoz kapcsolódóan illetik meg az azt igénybe vevő, illetve abban részesülő személyeket. Alanyuk tehát nem a betegségben szenvedő ember, hanem a beteg mint az egészségügyi szolgáltatás igénybevevője. Ezt támasztja alá az Egészségügyi Világszervezet (WHO) Amszterdami Deklarációként ismert dokumentuma, ${ }^{4}$ amely a pácienst kezeli az egyes jogosultságok alanyaként, akit az értelmező rendelkezések körében az egészségügyi szolgáltatás igénybe vevőjeként definiál, tekintet nélkül arra, hogy orvosszakmai szempontból beteg-e vagy egészséges. Az Eütv. ${ }^{5}$ az egyes betegjogok felsorolásakor szintén a beteget mint az egészségügyi ellátást igénybe vevő vagy abban része-

Halmai Gábor-Tóth Gábor Attila (szerk.): Emberi jogok. Osiris, Budapest, 2008, 88.

3 AdorJÁn Lívia-Sımkó Ágnes: A betegek jogairól. Medicina, Budapest, 2012, 9.

4 Az egyezmény teljes megnevezése: Principles of the Rights of Patients in Europe: a common framework.

5 Az egészségügyről szóló 1997. évi CLIV. törvény (Eütv.). 
sülő személyt ${ }^{6}$ jelöli meg alanyként. $A$ német $B G B^{7}$ sajátos megoldást alkalmazva a kezelést nyújtó fél szerződéses kötelezettségeiként ${ }^{8}$ jeleníti meg a betegjogokat, azok tehát kizárólag az „orvos-beteg” jogviszonyban érvényesülhetnek. Bár egyes jogosultságok csak a betegségben szenvedő személyek esetében értelmezhetők, ${ }^{9}$ a betegjogok alanya az egészségügyi ellátásban részesülö természetes személy. A betegjogokat tehát nem definiálhatjuk az embert a betegség állapotában megillető jogok összességeként.

A fentiekből következik, hogy a betegjogok az emberi jogoktól eltéröen nem az állammal szemben állítanak fel kötelezettségeket, hanem a jogviszony másik pólusát képező egészségügyi szolgáltatóval szemben. Az e jogosultságokra vonatkozó explicit szabályozás kimunkálása azonban szorosan kötődik az állampolgárok jóllétéhez kapcsolódó állami szerepvállaláshoz.

\section{A betegjogok megjelenése Európában}

Az egészségügyi szolgáltató kártérítési felelősségére vonatkozóan - annak ellenére, hogy egészen korai esetek is ismertek, és a 19. század végén már hazánkban is rögzítették az orvos mühibákért való felelősségét ${ }^{10}-a z$ orvos, illetve az egészségügyi intézmény egészségügyi szolgáltatás nyújtásával összefüggésben viselt felelőssége érvényesítésének hosszú ideig nem voltak megfelelő jogi keretei. Bár a felelősség megállapításának elvi lehetősége a vonatkozó jogszabályokban megjelent, az egészségügyi tevékenységgel összefüggő felelősségrevonás tényleges jogi alapját a betegjogok teremtették meg.

Az orvosi tevékenység átfogó, a területen évezredeken át irányadó hivatásetikai elveket felváltó jogi szabályozásának megalkotására, illetve a beteget az egészségügyi szolgáltatással összefüggésben megillető jogok meghatározására vonatkozó társadalmi igény a nürnbergi orvosper hatására került előtérbe. ${ }^{11} \mathrm{Az} 1947$. augusztus 19. napján tartott ülésen a Walter Beals bíró által vezetett tanács közzétette az emberen végzett kísérletekre vonatkozó etikai elveket. ${ }^{12} \mathrm{~A}$ később Nürnbergi Kódexként ismertté vált tíz pont tehát az orvostudományi kutatásokra vonatkozó alapvető szabályokat volt hivatott lefektetni, az első pontot képező tájékozott beleegyezés követelménye azonban az orvos-beteg kapcsolatok legfontosabb alapelvévé vált, ${ }^{13}$ amely egyúttal az egészségügyi szabályozás fejlődésének kiindulópontját jelentette.

6 Eütv. 3. § a) pont.

Bürgerliches Gesetzbuch in der Fassung der Bekanntmachung vom 2. Januar 2002 (BGBI. I S. 42, 2909; 2003 I S. 738).

8 BGB $\S \S 630 \mathrm{c}-\mathrm{g}$.

9 Életmentő ellátáshoz való jog (Eütv. 6. §).

10 1876. évi XIV. tc. 47. § „A gyakorlatra jogositott orvos a gyógymód alkalmazásában nem korlátoltathatik, müködésére nézve azonban az állam ellenőrködése alatt áll, és az általa elkövetett mühibákért felelös."

11 JoBBÁGYı Gábor: Orvosi jog. Szent István Társulat, Budapest, 2010 [a továbbiakban: JoBBÁGYI (2010)], 23.

12 WeIndLING, Paul: The Origins of Informed Consent: The International Scientific Commission on Medical War Crimes, and the Nuremberg Code. Bulletin of the History of Medicine, 75.1, 2001, 37.

13 WEINDLING, Paul: The Nuremberg Trials and their Legacy. Denning Law Journal, Vol. 27., 2015, 272. 
A betegjogoknak az európai jogrendszerekben való megjelenése szempontjából kiemelendők egyes olyan nemzetközi emberi jogi deklarációk, amelyek bár nem kifejezetten egészségügyi tárgyúak, mégis hatással voltak a részes államok egészségügyi szabályozására. Az Európa Tanács keretei között létrejött Emberi Jogok Európai Egyezménye (EJEE) alapján számos egészségügyi tárgyú keresetet nyújtottak be az Emberi Jogok Európai Bíróságához. ${ }^{14}$ Szintén az Európa Tanács keretei között jött létre 1997-ben az emberi jogokról és a biomedicináról szóló oviedói egyezmény, amely - az 1 . cikkben rögzített célkitüzés szerint - kifejezetten az orvostudomány alkalmazásának vonatkozásában védi az emberi lény méltóságát és sérthetetlenségét. Amint az címéből is kitünik, ez az egyezmény már nem csupán az orvostudományi kutatásokat vonja a hatálya alá, hanem az egészségügyi ellátásokat is. Figyelembe véve továbbá a fent említett célkitüzést, illetve hogy a preambulum az EJEE mellett egyéb nemzetközi emberi jogi egyezményekre is utal, egyértelműen összekapcsolja a betegjogokat az alapvető jogokkal.

A betegjogok és az emberi jogok kapcsolata szempontjából jelentős még a már említett Amszterdami Deklaráció (1994), amely a szabályozás vezérelvei körében rögzíti, hogy az ott felsorolt betegjogok fogalmi alapjai az emberi jogi tárgyú kormányközi egyezményeken nyugszanak. Fontos továbbá, hogy a dokumentum célja nem újabb jogosultságok megfogalmazása volt, hanem az, hogy az ezen egyezményekben már elismert jogokat átfogó és koherens módon specializálja az egészségügy területén.

Az európai jogfejlődés kapcsán említést kell tenni végül az Európai Unió jogának a betegjogokhoz való viszonyáról. Az emberi egészség védelme az Unió támogató, összehangoló, illetve kiegészítő hatáskörei közé tartozik, ${ }^{15}$ így az e területen elfogadott jogi aktusok nem irányulhatnak a tagállamok egészségügyi szabályozásának harmonizációjára. ${ }^{16} \mathrm{Az}$ emberi egészség védelme azonban az Európai Unió müködésével érintett területeken is jelentős kérdés. Az EUMSZ. népegészségügyről szóló 168. cikke ezért előírja, hogy valamennyi uniós politika meghatározása és végrehajtása kapcsán biztosítani kell az emberi egészségvédelem magas szintjét, egyúttal meghatározza, hogy az Unió milyen körben léphet fel ennek érdekében, végül hangsúlyozza, hogy tevékenysége során tiszteletben kell tartania a tagállamoknak az egészségügyi politikájuk meghatározására, valamint az egészségügyi szolgáltatások és az orvosi ellátás megszervezésére és biztosítására vonatkozó hatáskörét. $A$ betegjogok tehát egyértelműen a tagállami szabályozás körébe esnek. Ennek kapcsán megjegyzendő, hogy a Bizottság Egységesebb Európai Szerződési Jog Létrehozására Irányuló Akcióterve ${ }^{17}$ keretében létrejött Közös Referenciakeret Tervezet (DCFR) ${ }^{18}$ modellszabályként rögzíti a kezelési szerződés koncepcióját, amely szerződéses kötelemként határozza meg az egészségügyi szolgáltató tájékoztatási

14 Hervey, Tamara K.-McHale, Jean V.: Health Law and the European Union. Cambridge University Press, Cambridge, 2004, 23.

15 Az Európai Unió Működéséről Szóló Szerződés (EUMSZ) 6. cikk a) pont.

16 VÁrnay Ernő-PApp Mónika: Az Európai Unió joga. CompLex, Budapest, 2010, 186.

17 COM 2003/C 63/01 - Action Plan on a More Coherent European Contract Law.

18 Principles, Definitions and Model Rules of European Private Law, Draft Common Frame of Reference, http://ec.europa.eu/justice/contract/files/european-private-law_en.pdf (2017. 01. 08.). 
kötelezettségét, a tájékozott beleegyezés követelményét, az egészségügyi dokumentáció vezetésére vonatkozó kötelezettséget, valamint - utóbbival összefüggésben - a dokumentáció megismerésének jogát. Az uniós ajánlás a betegjogok emberi jogi gyökereit mellözve a szolgáltatásra koncentrál, és a beteget az egészségügyi szolgáltatással összefüggésben megillető jogok szerződéses kötelezettségként történő szabályozását szorgalmazza.

Az Európai Közösségekre vonatkozó szabályozás eleinte nem érintette az emberi jogokat, sőt az Európai Bíróság kezdetben következetesen visszautasította az alapjogoknak a közösségi keretek között történő biztosítására vonatkozó igényeket. Később a Bíróság attitüdje fokozatosan változni kezdett, amely az alapvető jogoknak az uniós jog általános elveként történő elismeréséhez, majd az Unió Alapjogi Chartájának megalkotásához vezetett. ${ }^{19} \mathrm{~A}$ Charta a személyi sérthetetlenséghez való jog kapcsán kifejezetten kitér az orvostudomány és a biológia területén érvényesülő jogokra, amelyek körében rögzíti az érintett személy szabad és tájékoztatáson alapuló, a törvényben megállapított eljárásoknak megfelelő beleegyezésének szükségességét. ${ }^{20} \mathrm{Az}$ Alapjogi Charta tehát a testi integritáshoz való jog elemeként kezeli a tájékozott beleegyezés követelményét, e megközelítésből kiindulva pedig a fenti követelményböl levezethető egészségügyi önrendelkezési jog is kezelhető alapvető jogként. Az önrendelkezési jog alapján ugyanis az érintett dönthet arról, hogy igénybe vesz-e egészségügyi szolgáltatást, avagy sem, ez a jogosultság pedig az egészségügyi ellátás nyújtására irányuló jogviszony keretein kívül is értelmezhető. Az önrendelkezési jogot biztosítani hivatott jogosultságok képezik tehát az emberi jogok és a betegjogok között húzódó határvonalat.

\section{A paternalizmustól a modern egészségügyi szabályozásig: a betegjogok fejlődése Magyarországon}

A kilencvenes évek elején a legtöbb európai államhoz hasonlóan a magyar jogrendszer sem ismerte a betegjogok fogalmát. Az egészségügyröl szóló 1972. évi II. törvény (régi Eütv.) a szocialista jogrendszerekre jellemző paternalista szemléletet érvényesítette az egészségügy területén is. Az egészségügyi szolgáltatás nyújtására irányuló jogviszonyt így államigazgatási jogviszonyként fogták fel: „Csak az államigazgatási jogi szabályozás teszi lehetővé, hogy ilyen bonyolult érdekviszonyok között [...] teljes egészében védelmet kapjanak mind a társadalom, mind a beteg, mind pedig az egészségügyi szolgáltatást nyújtó intézet jogos érdekei."21 A beteg tehát alárendelt ügyfélként vette igénybe az egészségügyi szolgáltatást, ${ }^{22}$ az előző fejezetben ismertetett jogosultságokhoz hasonló betegjogi tárgyú rendelkezéseket a régi Eütv. nem tartalmazott.

\footnotetext{
19 VÁRnAY-PAPP: i. m., 245-257.

20 Az Európai Unió Alapjogi Chartája, 3. cikk (2) bekezdés a) pont.

21 BeRÉnYI Sándor-Martony János-SzAmel Lajos: Magyar államigazgatási jog. Általános rész. Tankönyvkiadó, Budapest, 1980, 295.

22 JoBbÁGYI (2010): i. m., 37.
} 
Ezzel összefüggésben meg kell említeni, hogy a régi törvény már hatályba lépésétől fogva rögzített egy, az orvos tájékoztatási kötelezettségére vonatkozó rendelkezést. Eszerint az orvosnak az általa kezelt beteget, illetőleg hozzátartozóját vagy - ha a beteg gyógykezelése érdekében szükséges - gondozóját a betegségröl és a beteg állapotáról megfeleló módon tájékoztatnia kell. Indokolt esetben a beteg érdekében ettöl eltekinthet. ${ }^{23} \mathrm{Ez}$ a követelmény azonban nem biztosította a beteg számára az önrendelkezési jogot, a fenti rendelkezés ugyanis csupán a tájékoztatás tartalmát határozta meg, nem támasztott elvárásokat a tájékoztatás mikéntjére vonatkozóan, nem biztosította tehát, hogy a tájékoztatás megfelelő időben, az érintett számára érthető formában történjen. Ha pedig mégis érthető módon közölték a beteggel, hogy milyen betegségben szenved, illetve milyen a pillanatnyi egészségi állapota, még mindig nem rendelkezett ismeretekkel a betegség lefolyásáról, a szóba jöhető gyógymódokról, azok kockázatairól stb., vagyis az érintett a törvényben rögzített minimumkövetelmények teljesülése esetén sem tudott volna felelős döntéseket hozni az öt érintő ellátással összefüggésben. Ezt tetézi, hogy amennyiben az ellátást nyújtó orvos megítélése szerint ez a „beteg érdekét” szolgálta, még a fenti tájékoztatástól is el lehetett tekinteni. A régi Eütv. továbbá csak bizonyos beavatkozások, így például a fekvőbeteg-gyógyintézetben kezelt beteget érintő műtétek ${ }^{24}$ vagy vérvétel ${ }^{25}$ esetén követelte meg a beteg hozzájárulását, így a betegautonómia garanciái a fentiek szerint még nem voltak biztosítottak. Az ágazatra vonatkozó törvényi szabályozás tehát teret engedett az egészségügyben hosszú ideje uralkodó paternalista szemléletnek.

A rendszerváltást követően egyre erőteljesebbé vált a betegjogok törvényi szabályozása iránti társadalmi igény, amely olyan tényezők mellett, mint az egészségbiztosítási rendszer bővülése, az orvostudomány fejlődése, illetve új technikai eszközök megjelenése, új egészségügyi ágazati kódex megalkotását tette szükségessé. ${ }^{26}$ A kormány ezért kormányhatározatban rögzítette az új törvény elveit, a jogalkotással kapcsolatos feladatokat. ${ }^{27}$

A kormányhatározat a törvényhozási munkálatok alapelveit az Európai Unió és az Egészségügyi Világszervezet ajánlásaival és állásfoglalásaival összhangban alakította ki, amelyek között első helyen szerepelt az egészség védelméhez és az egészségügyi szolgáltatások igénybevételéhez füződő alapvető jog, mint az egészségügyi szabályozás megalkotásában és az egészségügyi ellátórendszer fenntartásában megnyilvánuló állami szerepvállalás emberi jogi alapja. A kormányhatározat a fentiek mellett az állam feladataként jelöli meg az ember személyiségi és önrendelkezési jogának, méltóságának teljes körű védelmét és biztosítását az egészségügyi ellátások során, továbbá felsorolja az egészségügyi ellátással összefüggésben a beteget megilletö, törvényben rögzített jogokat.

23 Régi Eütv. 45. § (1) bek.

24 Régi Eütv. 47. § (4) bek.

25 Régi Eütv. 49. $\$(2)$ bek.

26 Heuer Orsolya (szerk.): Betegjogok Magyarországon - szabályok és gyakorlat. TASZ, Budapest, $2002,4$.

27 1093/1996. (VIII. 30.) Korm. határozat az egészségügyi törvény főbb elveiről és az előkészítésével kapcsolatos feladatokról. 
Az Eütv. önálló fejezetben katalogizálja a fentieknek megfelelően megfogalmazott betegjogokat. A törvény II. fejezete összesen kilenc jogosultságot nevesít. Az egészségügyi ellátáshoz és az emberi méltósághoz való jog deklarálása mellett a beteg autonómiáját biztosítani hivatott klasszikus betegjogok a tájékoztatáshoz és önrendelkezéshez való jog, illetve az ellátás visszautasításának joga formájában jelennek meg. Az adatkezeléssel és -védelemmel kapcsolatos általános követelmények az egészségügyi dokumentáció megismerésének jogaként, illetve az orvosi titoktartáshoz való jogként szintén önálló jogosultságokként kerültek a törvénybe. A kapcsolattartás joga és az intézmény elhagyásának joga a fent bemutatott egyezményekben nem képeznek sui generis betegjogokat. Az előbbi olyan részjogosultságokat tartalmaz, amelyek a családi kapcsolatokhoz füződő jogot, illetve a szabad vallásgyakorlás jogát biztosítják a beteg számára.

Az intézmény elhagyásának joga szorosan kapcsolódik az önrendelkezési joghoz, így magától értetődik, hogy a beteg szabadon távozhat a kórházból. A mások testi épségének, illetve egészségének védelméhez füződő érdekek azonban gyakorta szükségessé teszik a beteg szabad mozgásának korlátozását. Az ehhez kapcsolódó feltételek pontos meghatározásának igénye pedig indokolttá teszi az intézmény elhagyása jogának mint önálló betegjognak a rögzítését. Ezzel összefüggésben meg kell említeni az Eütv. pszichiátriai betegekre vonatkozó X. fejezetét, amely folyamatos bírói kontrollt biztosítva fokozottan védi az érintettek személyi szabadságát. E betegek egészségi állapota ugyanis olyan korlátozó eszközök szükségességét veti fel, amelyek az alapvető jogok sérelmének fokozott veszélyét hordozzák magukban. A korlátozó intézkedések alkalmazásának rendjét külön rendelet ${ }^{28}$ szabályozza, azt azonban, hogy ezeket csak olyan betegeken lehessen alkalmazni, akiknek valóban indokolja az egészségi állapota, törvényi garanciák biztosítják.

A korlátozás kérdését azonban valamennyi betegjog kapcsán szabályozza a törvény. Ezek többnyire az egészségügyi ellátás zavartalanságához, illetve - a fentiekhez hasonlóan - a beteg és más személyek testi épségének és egészségének védelméhez kapcsolódnak. Kijelenthető tehát, hogy az egészségügyi ellátások igénybevételével összefüggésben nem csak az alapjogok érvényesülése igényel közelebbi szabályozást. A beteget megillető alapvető jogok korlátozásának sajátos feltételei szintén megkövetelik a betegjogok törvényi rögzítését.

Az Eütv. hatálya kiterjed valamennyi, Magyarország területén tartózkodó természetes személyre, az itt müködő egészségügyi szolgáltatókra, illetve itt folytatott egészségügyi és egészségfejlesztési tevékenységre. A törvényben rögzített betegjogok tehát - az ellátás jogcímére való tekintet nélkül - feltétlen érvényesülést követelnek az egészségügy valamennyi területén, így beépülnek az egészségügyi szolgáltató és a beteg jogviszonyába is.

Az Eütv. II. fejezetének szerepe nem korlátozódik a beteg alapvető jogai érvényesülésének biztosítására. Az Európa-szerte egységes szakirodalmi álláspont szerint az egészségügyi szolgáltatás nyújtására irányuló jogviszony magánjogi, szerző-

28 A pszichiátriai betegek intézeti felvételének és az ellátásuk során alkalmazható korlátozó intézkedések szabályairól szóló 60/2004. (VII. 6.) ESZCSM rendelet. 
déses kötelék, amelyben a felek autonómok, egyenjogúak és mellérendeltek. ${ }^{29} \mathrm{Az}$ egészségügyi szolgáltatás nyújtásával összefüggésben a betegnek okozott károkkal kapcsolatos perekben kialakult hazai bírói gyakorlat szintén ezt a szemléletet képviseli. ${ }^{30}$ Ennek ellenére sem a Polgári Törvénykönyvröl szóló 2013. évi V. törvény (Ptk.), sem az ágazati jogszabályok nem szabályozzák önálló szerződéstípusként a „kezelési szerződést”. Az Eütv.-ben felsorolt betegjogok viszont részletekbe menően meghatározzák az ellátás mint szolgáltatás nyújtásának módját, illetve az egészségügyi szolgáltatáshoz kapcsolódó jogosultságokat. Az Eütv. VI. fejezete rögzíti továbbá az egészségügyi dolgozóknak az ellátás nyújtása során terhelő kötelezettségeit. A fenti kötelezettségek korrelációban állnak a II. fejezetben felsorolt betegjogokkal, biztosítva ezzel utóbbiak érvényesülését. A felek jogállását, illetve a jogviszony tárgyát képező egészségügyi szolgáltatás nyújtásának módját tehát az Eütv. II., illetve VI. fejezetei együtt határozzák meg.

Az egészségügyi tevékenység végzésének jogi kereteit, illetve az egészségügyi dolgozók foglalkoztatásával összefüggésben irányadó követelményeket részletesen szabályozza továbbá az egészségügyi tevékenység végzésének egyes kérdéseiről szóló 2003. évi LXXXIV. törvény (Eütev.). Az Eütev. 5. § (2) bekezdése ugyan általános követelményként rögzíti a beteg személyiségének, méltóságának és jogainak tiszteletben tartását, továbbá a páciens életkorának, valamint önrendelkezésének figyelembevételét, ez azonban csak közvetett hatást gyakorol a felek jogviszonyára, illetve a betegjogokra. Az egészségügyi tevékenységre vonatkozó - szektorsemleges követelmények törvényi rögzítését azonban az egészségügyi ellátás megfelelő színvonalának biztosítása iránti társadalmi igény indokolja. Az egészségügyi dolgozók hivatásgyakorlására vonatkozó általános feltételek lefektetése tehát - a betegjogokhoz hasonlóan - az állampolgárok egészsége érdekében vállalt állami kötelezettség teljesítéseként értékelhető.

\section{A betegjogi szabályozás kialakulása Németországban}

A német jogirodalom, illetve bírói gyakorlat évtizedek óta határozottan szerződéses kötelékként tekint az egészségügyi szolgáltatás nyújtására irányuló jogviszonyra. ${ }^{31}$ Ezt az álláspontot a Szövetségi Alkotmánybíróság is megerősítette az alábbiak szerint: „Az orvos és a beteg közötti jogviszony Eberhard Schmidt szerint sokkal több, mint egy szerződéses kapcsolat. Az orvosetika nem különül el a jogi szabályozástól, folyamatosan jelen van az orvos betegekkel való kapcsolataiban. Az etikai normák által támasztott követelmények jogi kötelezettségekként is megjelennek. Az orvosi tevékenység esetében az etikai szabályok sokkal jobban összefolynak a jogi normákkal,

29 JoBbÁGYI (2010): i. m., 37.

30 A Legfelsőbb Bíróság Civilisztikai Kollégiumának emlékeztetője a civilisztikai kollégiumvezetők 2008. január 23-25. napján megtartott országos tanácskozásán megvitatott kérdésekröl, http://ibolyatibor.atw.hu/civkoll. pdf (2014. 10. 09.).

31 JоввÁGYI Gábor: Orvosi kezelési szerződés - új szerződésfajta a BGB-ben. In: Tanulmányok a 65 éves Lenkovics Barnabás tiszteletére. Eötvös József Könyv- és Lapkiadó Bt., Széchenyi István Egyetem Deák Ferenc Állam- és Jogtudományi Kara, Budapest-Győr, 2015 [a továbbiakban: JoBBÁGYı (2015)], 193. 
mint bármely más területen. Ez napjainkban is így van, a beteg önrendelkezési jogának figyelembevétele lényeges eleme az orvosi kötelezettségek körének."32

A Szövetségi Alkotmánybíróság a fentieket a beteg tájékozott beleegyezéséhez füződő követelmény kapcsán mondta ki. Amint arról a fentebbi fejezetek is említést tesznek, a tájékozott beleegyezés követelménye a betegautonómia legfőbb garanciája, amely biztosítja, hogy a betegen kizárólag olyan beavatkozást végezhessenek el, amelybe - annak jellege, célja, módszere, kockázatai ismeretében - beleegyezett. Nem elég tehát deklarálni az orvos-beteg kapcsolat szerződéses jellegét, a szerződés tárgyát képező szolgáltatás ugyanis közvetlenül érinti a beteg biológiai egzisztenciáját, így olyan szabályozásra van szükség, amely a beteg autonómiájának biztosítása mellett a kezeléssel érintett alapvető jogok, különösen az élethez való jog és az emberi méltósághoz való jog védelmét is garantálja az ellátás során.

Németországban - egészen a BGB 2013. évi módosításáig - a beteget az egészségügyi ellátással összefüggésben megillető jogok nem voltak katalogizálva, azokat a bírói gyakorlat munkálta ki az egészségügyi szolgáltató kezelési hibákért való felelősségével kapcsolatos perekben. A Szövetségi Orvosi Kamara (Bundesärztekammer) szakmai szabályzata ${ }^{33}$ ezt megelőzően is rögzített betegjogi hátterü követelményeket, így többek között az emberi méltóság tiszteletben tartását, ${ }^{34}$ a tájékoztatási kötelezettséget, ${ }^{35}$ illetve a dokumentációs kötelezettséget, ${ }^{36}$ átfogó betegjogi szabályozás azonban nem létezett. Ez a jogbizonytalanság - elsősorban azért, mert hiányzott a tájékoztatási kötelezettség körének pontos meghatározása - az egészségügyi szolgáltató pozíciója szempontjából is kedvezőtlen volt. Bár a Szövetségi Legfelsőbb Bíróság (Bundesgerichtshof, a továbbiakban: BGH) a kezelési szerződés BGB-beli rögzítését megelőzően igyekezett átfogó módon rendezni a tájékoztatással kapcsolatos általános kérdéseket, illetve egységesíteni az ezzel kapcsolatos gyakorlatát, nem született olyan megoldás, amely a betegautonómia biztosítását és az orvos ellátási kötelezettségét egyensúlyba tudta volna hozni. ${ }^{37}$

A jogbiztonsággal és az alapvető jogok védelmével kapcsolatos megfontolások mellett kiemelendő, hogy az orvosi felelősség - a gazdag bírói esetjognak köszönhetően - kiterjedt, komoly gyakorlati relevanciával bíró területté fejlődött, így e szempontból is indokoltnak tekinthető a betegjogok, illetve az egészségügyi szolgáltató és a beteg közötti kötelék törvényi szabályozása. ${ }^{38}$

A betegjogok szabályozására vonatkozó igény azonban - amint az a hazai szabályozás történetét áttekintve is látható - nem jelenti azt, hogy a kezelési szerződést feltétlenül önálló szerződéstípusként kellene szabályozni. Az egészségügyi szolgáltatások nyújtásának szabályozása körében - legalábbis Európában - fontos tényező, hogy a beteg az esetek többségében társadalombiztosítási ellátás-

BVerfG, 25.07.1979 - BvR 878/74 (108).

33 (Muster-)Berufsordnung für die in Deutschland tätigen Ärztinnen und Ärzte - MBO-Ä 1997.

MBO-Ä § 7 Abs. 1.

MBO-Ä $\S 8$.

MBO-Ä § 11 .

Katzenmeier, Christian: Arzthaftung. Mohr Sibeck Verlag, Tübingen, 2002, 354.

38 FRANZKI, Dominik: Der Behandlungsvertrag. Ein neuer Vertragstypus im Bürgerlichen Gesetzbuch. Universitätsverlag Göttingen, Göttingen, 2014, 42. 
ként vesz igénybe egészségügyi szolgáltatást, az ilyen ellátásokra pedig nem lehet tisztán - szerződéses megállapodás alapján nyújtott - szolgáltatásként tekinteni. A BGB módosítását is tartalmazó betegjogi törvény (PRG) ${ }^{39}$ előkészítése során - az egészségbiztosítási vonatkozások kapcsán - felmerült tehát a közjogi szabályozás lehetősége is. Az úgynevezett ellátási koncepció (Versorgungskonzeption) szerint az orvos az egészségügyi szolgáltatást a betegnek mint biztosítottnak egészségbiztosítási ellátásként nyújtja, így az ellenszolgáltatást sem a beteg, hanem az egészségbiztosító teljesíti, ez a jogviszony tehát nem tekinthető magánjoginak. ${ }^{40}$

A BGH gyakorlata, ${ }^{41}$ illetve a szakirodalom ${ }^{42}$ szerint mégis az a meghatározó, hogy a biztosított az egészségügyi szolgáltatóval kötött szerződés alapján veszi igénybe az ellátást. Ezt támasztja alá a beteg autonómiájának elismerése, az orvos gyógymódválasztási szabadsága, illetve az orvos és a beteg közötti bizalmi kapcsolat. A fenti ismertetőjegyek az egészségbiztosítási ellátásként nyújtott kezelés esetében is jellemzik az orvos-beteg köteléket, a német jogalkotó ezért a magánjogi szabályozás mellett döntött: ${ }^{33}$ a PRG-vel történt módosítását követően a BGB sui generis szerződéstípusként rögzíti a kezelési szerződést (Behandlungsvertrag). ${ }^{44}$

Németországban tehát a kezelési szerződés BGB-beli rögzítését megelőzően a betegjogok az egészségügyi szolgáltatások igénybevételével összefüggésben keletkezett károkért való felelősséggel kapcsolatos bírói gyakorlat által kimunkált formában léteztek. Azonban, részben a fentebb említett alkotmányjogi megfontolások, de föként az egészségügyi szolgáltató felelősségre vonásának kereteit tisztázó szabályozás iránti igény miatt elengedhetetlenné vált egy átfogó betegjogi szabályozás megalkotása. Az orvos és a beteg közötti kapcsolat magánjogi vonásaira tekintettel a jogalkotó az egészségügyi szolgáltatással összefüggésben a beteget megilletö jogokat szerződéses kötelezettségként határozta meg.

A BGB a betegjogok körében az egészségügyi szolgáltató tájékoztatási kötelezettségét, a tájékozott beleegyezés követelményét, az egészségügyi dokumentáció vezetésére vonatkozó kötelezettséget, valamint - utóbbival összefüggésben - a dokumentáció megismerésének jogát rögzíti. A törvény taxatív módon határozza meg továbbá azokat az esetköröket, amikor a fenti kötelezettségek nem terhelik az egészségügyi szolgáltatót, ily módon pedig a BGB is garantálja a beteg autonómiájának biztosítását célzó rendelkezések feltétlen érvényesülését.

\section{5. Összegző gondolatok}

A betegjogok gyökere a Nürnbergi Kódexben rögzített tájékozott beleegyezés követelményében keresendő, amelynek elvi alapját az emberi test integritásának védelme képezi. A nürnbergi orvospert követően számos, a nemzetközi emberi

39 Gesetz zur Verbesserung der Rechte von Patientinnen und Patienten vom 20. Februar 2013. (PRG).

40 FRANZKI: i. m., 50.

41 BGH, 17.12.1985 - VI ZR 178/84 stb.

42 JoBbÁGYI (2015): i. m., 193.

43 FRANZKI: i. m., 51.

44 BGB $§ 630$. 
jogi dokumentumokra alapozó, betegjogi tárgyú kormányközi egyezmény született, amelyek - az egészségügy sajátosságait figyelembe véve - mintegy újraértelmezték az alapjogokat. Ezek az egyezmények - bár erre csak később, a kilencvenes évek elején került sor - lehetővé tették, hogy a részes államok beemeljék jogi szabályozásukba a fenti dokumentumokban általuk, illetve NGO-ik ${ }^{45}$ által elismert jogokat. A beteget az egészségügyi ellátással összefüggésben megillető jogosultságok tehát közvetlen kapcsolatban állnak az alapjogokkal: az emberi jogok a betegjogokon keresztül érvényesülnek az egészségügy területén.

A betegjogok azonban más összefüggésben is kiszélesítik az emberi jogok érvényesülési körét. Az emberi jogok önmagukban csak az egyén és az állam relációjában képesek joghatást kiváltani. Bár a személyiségi jogok védelme napjainkra meglehetősen hangsúlyos területté vált, a klasszikus személyiségi jogi jogvitáktól eltekintve az emberi jogok kérdése továbbra is szűk körben merül fel a magánjogi jogviszonyokkal összefüggésben. Különösen igaz ez a szerződéses kötelékekre, amelyekben a polgári jogi viszonyok gazdasági jellege a meghatározó. Vannak persze kapcsolódási pontok: az üzleti kapcsolatok szereplői nagy hangsúlyt fektetnek a jó hírnevük védelmére, amelyhez kapcsolódó szerződéses és jogszabályi garanciák azonban nem a személyiségi jogok jelentősége miatt nélkülözhetetlenek, sokkal inkább a gazdasági egzisztencia védelmét hivatottak biztosítani.

Más a helyzet az adatvédelmi szabályozással, amely napjainkban egyre szélesebb körben érinti a gazdasági kapcsolatokat és a fogyasztói szerződéseket. Bár ezek a rendelkezések közvetlenül szolgálják az érintett fél személyiségi jogainak védelmét, és különböző jogviszonyok esetében eltérő tartalommal érvényesülnek, nem a szolgáltatás sajátos jellege, hanem a személyes adatok védelmének általános követelménye okán jelennek meg a szerződéses kapcsolatokban. Az emberi jogok tehát a legtöbb esetben még a személyiségi jogok közvetítésével sem gyakorolnak hatást a szerződéses jogviszonyokra.

Akadnak viszont sajátos kötelékek, amelyek esetében a gazdasági célok mellett egyéb megfontolások is szerepet játszanak. E körben meg kell említeni a munkavállalók személyiségi jogainak védelmét, amely egyre fontosabbá válik a modern munkajogban. A munkaviszony sajátosságaiból - így elsősorban a munkáltatói jogkörbe eső jogok jellegéből és a munkáltató gazdasági erőfölényéből - adódik, hogy a munkáltató rendelkezésére álló egyes eszközök az eredeti céljuktól eltérő körben érintik a munkavállalót, illetve annak személyiségi jogait. Az ebből eredő jogsértések elkerülése érdekében a munkajogi szabályozás pontosan meghatározza például a munkavállaló ellenőrzését lehetővé tevő jogosultságok gyakorlásának kereteit. Ezek a rendelkezések azonban csak közvetetten érintik a munkaviszony fő tárgyát képező munkavállalói és munkáltatói jogokat, illetve kötelezettségeket.

Az egészségügyi szolgáltatás nyújtására irányuló jogviszonyban egészen másként alakul a személyiségi jogok érintettsége, az egészségügyi beavatkozás ugyanis közvetlenül az emberi személyiség lényegét képező életet, egészséget és testi

45 A Helsinki Deklaráció 1964-ben az Orvosok Világszövetsége (WMA) keretei között jött létre, amely nem kormányközi szervezet, tagságát - többek között - az egyes államokban működő orvosi kamarák képezik. A Magyar Orvosi Kamara és a Bundesärztekammer egyaránt tagjai a WMA-nak. 
épséget érinti. Ezek a másik fél jogellenes magatartásától, illetve rosszhiszemű joggyakorlásától függetlenül is veszélybe kerülhetnek. Az „orvos-beteg” jogviszonyban tehát olyan abszolút jogokra van szükség, amelyek köre és érvényesülésük garanciái nem a felek megállapodásától vagy a jogviszonyuk sajátosságaitól függnek, hanem amelyeket az állam valamennyi érintett személy tekintetében feltétel nélkül elismer és kikényszeríthetővé tesz a másik féllel szemben. A betegjogok tehát e jogviszonyokban olyan, szinte közvetlen érvényesülést biztosítanak az alapjogoknak, amely egyébként idegen a szerződéses kapcsolatoktól.

Az Eütv. rendelkezései - az ellátás jogcímére tekintet nélkül - valamennyi egészségügyi szolgáltatásra kiterjednek, és közjogi szabályozásként feltétlen érvényesülést követelnek. Az itt rögzített betegjogok az ágazati szabályozás általános követelményeiként épülnek be az egészségügyi szolgáltatás nyújtására irányuló szerzödésekbe. A német szabályozás ezzel szemben a jogviszony szerződéses jellegéből indul ki. A BGB-ben a legalapvetőbb betegjogok az egészségügyi szolgáltató kezelési szerződésből fakadó kötelezettségeiként jelennek meg az egészségügyi szolgáltató oldalán. Ezek azonban - a BGB-ben meghatározott esetek kivételével - eltérést nem türő, kógens követelmények, így mégis feltétlen érvényesülést biztosítanak a betegjogoknak.

Szembetűnő azonban, hogy amíg az Eütv. a beteget megillető abszolút jogok katalógusát rögzíti, addig a BGB az egészségügyi szolgáltatások sajátosságaihoz igazodva önálló szerződéstípust szabályoz. Bár a legfontosabb betegjogok itt is megjelennek, a német szabályozás a felek jogviszonyára és a szolgáltatás tárgyára koncentrál, így a beteget inkább szerződő félként védi, mintsem emberi lényként. Mivel azonban az egészségügyi szolgáltatót a kezelési szerződés alapján terhelő kötelezettségek korrelációban állnak az Eütv.-ben, illetve a tárgyalt nemzetközi egyezményekben rögzített betegjogokkal, a BGB rendhagyó „betegjogi szabályozása” egyedi példája az emberi jogok szerződéses kapcsolatokban való érvényesülésének.

\section{Abstract}

Medical practice affects human life and health, which are not just some of the key social values, but actually express the existence of a human being. Therefore, it is a requirement to set the legal standards to guarantee the preservation and respect of human rights during medical treatment. Patients' rights provide specific types of human rights in the area of patient care. The German legal system grants the preservation of these rights in a contractual framework that cannot be breached. In Hungary, patients' rights are listed in the Public Health Act. Despite the diverse methods in regulating patients' rights, the underlying public policy considerations are the same in both systems. The goal of this study is to provide a comparative analysis on the development of the German and the Hungarian regulation of patients' rights focusing on the consideration of human rights. 